\title{
The Impact of Capital Structure and Financial Performance on Stock Returns in India: A Review
}

\author{
Harry Tettey Tetteh', Frank Asante Bediako², Mrinal Jha ${ }^{3}$, \\ Rohit Bansal* and Suresh Kumar Kashyap \\ ${ }^{1}$ Professor, Mittal School of Business, Lovely Professional University, Phagwara, \\ ${ }^{123}$ MBA Students, Mittal School of Business, Lovely Professional University \\ ${ }^{2}$ Assistant Professor, Mittal School of Business, Lovely Professional University, Phagwara
}

\section{ABSTRACT}

Changes in the capital structure and financial performance are of central importance in assessing the overall returns of firms and, more importantly, in knowing whether stock returns are sensitive to changes in the capital structure. In order to quantify this impact, stock returns were taken as dependent variables and debt to equity, return on equity ratios, earnings per share were used as independent variables. The results were drawn from the mentioned variables using the regression model. Debt-to-equity ratio, return-to-equity ratio, earnings per share have a positive effect on stock return. Based on the finding, it was concluded that the change in capital structure and firm performance had an impact on the stock returns.

KEY WORDS: CAPITAL STRUCTURE, FINANCIAL PERFORMANCE, STOCK RETURNS, IMPACT, FIRMS.

\section{INTRODUCTION}

Capital structure is particular mix of debt and equity a company uses to finance its entire improvement as a result. Deficits occur from loans as well as government bonds, whereas capital may come as part of corporate equity ownership, cumulative preferred stock, or retaining. Current liabilities are assumed to be part of capital structure. The current research report is based on the impact capital structure has on financial performance and its effects on return on equity, so the study points out that the variance and effects of certain aspects of the capital structure is related to the relationship between aspects such as the relationship of variables such as Return on

\section{ARTICLE INFORMATION}

Received 29th Oct 2020 Accepted after revision 12th Dec 2020 Print ISSN: 0974-6455 Online ISSN: 2321-4007 CODEN: BBRCBA

Thomson Reuters ISI Web of Science Clarivate Analytics USA and Crossref Indexed Journal

\section{Clarivate
Analytics}

NAAS Journal Score 2020 (4.31)

A Society of Science and Nature Publication,

Bhopal India 2020. All rights reserved.

Online Contents Available at: http//www.bbrc.in/

Doi: http://dx.doi.org/10.21786/bbrc/13.15/9
Equity, return on investment, earnings per share on return on equity, relationship of both and return on equity, how it affects profitability, market valuation as well as assets of stakeholders, the relationship between leverage and return on equity, etc. The reason for evaluation and collection secondary data from independent individuals and recurring statements that can direct us to the desired outcome and identify how different factors affect the financial performance and what the impact of these factors on stock return is. Murtaza and Azam (2019) mention that ownership structure variables are also influenced by capital structure decisions.

In addition, the concentration of ownership is widely used worldwide, which is prominent in selecting the financial structure of the organization and as well as corporate governance practices. The ownership concentration concerns the number of shares owned by entities and main block shareholders (the company's top shareholders hold at least 5 percent of fair ownership). The ownership concentration has great effect on policymaking strategies for the capital structure. The study was therefore undertaken to justify the prevalence of research gap, 
to examine the relationship between the structure of ownership and capital structure. Ligocká and Stavárek (2019) note that several factors can affect stock prices. Some studies are attempting to classify them into two variables types that can be determined to have effect stock prices: macro and microeconomic variables. Up to 50 percent of stock prices are impacted by the individual characteristics of firms, according to an earlier study.

The analysis demonstrated the contribution of a lot of market and sector variables against European stock price fluctuations. The analysis is to define the financial ratios affecting the prices of listed food companies on the European stock exchanges, especially in Austria, Poland, and Switzerland. Al Salamat and Mustafa in (2016) described the relationship that exists between capital structure and stock return. A detrimental and important correlation between capital structure and stock return was found in the product of the regression model. A really important and positive association between turnover and return on assets as wells as equity return also is reported in the results. There is a positive but insignificant relation with the equity return for the company size and market to book ratio. Avci (2016) examines the relationship between companies' financial and real decisions on capital structure and performance. Between 2003 and 2015, study was performed on manufacturing companies trading in Borsa Istanbul.

To measure firm performance, equity return and asset return is used and as explanatory variables, short-term debt to total assets, long-term debt to total assets, and debt to equity are used; total assets are contingent variables. Both banks listed on the Tehran Stock Exchange in 2009-2016 are included in the statistical community. The results indicate beneficial consequences of the banks' financial structure, ROA and ROE. Moreover, the results show that the relationship between financial structure and ROA and ROE is substantially moderated by capital intensity and scale. Singh and Bansal (2016) examined the impact of financial leverage on the company's financial results and the company's value. Data from 58 Fast Moving Consumer Goods (FMCG) firms listed on the National Stock Exchange (NSE) and Bombay Stock Exchange (BSE) for a 10-year period from 2007 to 2016. This is the S\&P BSE FMCG Index. To research the effect of financial leverage on company efficiency and valuation, four regression equations were created. SPSS used the panel data regression methodology.

Results revealed that leveraging has a substantial negative effect on the company's EVA and ROA success indicators and Tobin's Q indicator. Rajhans (2013) objectively observed determinants of firm value creation. For this reason, 16 companies listed on the Bombay Stock Exchange (BSE) from 2002 to 2011, namely Metal, Fast Moving Consumer Goods (FMCG), Information Technology (IT and Automotive, were specified based on market capitalization in their industry. Data from 2002 to 2011 was all secondary data. Finding implies that the suggestion of Modigliani and Miller, i.e., Capital structure does not change a corporation's valuation. However, this research finding suggests that WACC has a major impact on the valuation of the firm. Other main factors identified by the proposed model are capital assets, net sales and profit.

Talwar (2020) studied the effect of accounting-based efficiency indicators, financial structure and corporate governance on company valuation, measured by Tobin's $\mathrm{Q}$, of Indian firms in the fast-moving consumer goods (FMCG), automotive (auto) and IT (IT) sectors from 2004 to 2017. The research used the Less Square Dummy Variables (LSDV) panel approach to show income growth, asset return, debt-equity ratio, and corporate governance were statistically important predictors of firm value for the sectors being tested. The Wald test showed the fixed-effect model to be more stable than the pooled regression model, confirming various dynamics for and area between the dependent and the explanatory variables. Since the influence of variables on firm value for manufacturing and service sectors was distinct, the main contribution of the results is that management should consider the sectoral effect when calculating firm value.

Literature Review: Study by (Murtaza \&t Israel, 2019) reported shipping firms' productivity in allocating resources. They also investigate the impact of ownership accumulation on business value. A sample size of 126 listed companies was evaluated for 19972016. The final findings of their study clarify that ownership concentration has a favorable impact on business valuation. Homaidi (2019) found a strong correlation between the two variables, indicating that the audit category size and board size have the highest transparency variables, while government ownership is the bottommost variable disclosed to tourism businesses. Research has showed that board composition has a favorable impact on a company's financial performance. It shows that the level of corporate transparency has a positive connection to the "board size, ratio of members of the audit team to total board members, family control, the duality of CEO, business size, profitability, liquidity." Ghosh (2019) performed research on major post-World War II oil price tremors like the 1956-57 Suez Crisis, the 1973-1974 OPEC oil embargo, the 1978-1979 Iranian Rebe. The study strengthened the understanding of economic penalties from oil price shocks.

Previous scholars studied the differential influence of oil price fluctuations on US economies and their policy insinuations. Among other items, the study highlighted why US consumers reacted so little when oil prices increased from \$41 per barrel in July 2004 to $\$ 65$ in August 2005 (a 59 percent increase), but otherwise responded to the rise in oil prices from $\$ 72$ in August 2007 to \$134 (an 86 percent rise) in June 2008. According to Ariyani et al (2019), the study has said that profitability is a metric for producing corporate profits. This incentive is a benefit goal that guarantees a return in the future. If the benefit target and the potential to raise profits is in line, so it may be concluded that the company performs efficiently. Here too, the two kinds 
of profitability ratios relative to sales and those related to spending will be discussed a bit. The revenue ratio is the margin of gross profit and net profits. Return on assets is the investment-related return on assets (ROA). Yudha et al (2019) The paper on the Indonesian Stock Exchange focuses on a phenomenon of lower stock prices for building and construction subsectors during government infrastructure development.

Using data panel regression, it analyzed the impact of financial performance and macroeconomics on the stock returns of the construction and construction subsectors of the Indonesian Stock Exchange. Government policies, Return on Equity (ROE), Price Book Value (PBV), inflation rates, Debt to Equity Ratio (DER) and have a great impact on construction projects stock returns and the Turn Over, Inventory Ratio and Price to Earnings Ratio of net assets, post-sectors have a huge impact on stock returns. Boller, L., F. S. Morton's. (2020) estimated that by exploring an alternate route to an economic-wide study, research supports common ownership literature. Research data allowed many businesses and companies to quantify the impact of shared ownership. These analyses allowed the experiment to draw a causal inference. It was determined that the strategy is constant with an upsurge in common ownership interpreting likely profits and increasing returns into the advanced future.

By assessing the value of our BTR scale, Dou (2019) investigated empirical analyses. By comparing the BAV data with Compustat/CRSP, external authentication analysis was performed to investigate the relationship between our BTR metric and various representations of meaningful reward. The study showed that firms with lower BTRs are related to higher one-year deferred management investment, REtD spending, and executive pay, indicating significant expertise is more important for businesses. The survey-based BTR test is unlikely to be mechanically related to the resulting financial variables, as opposed to other brand indicators extracted from company financial and accounting variables According to Nuber et al (2020), Continental Europe has a long custom of code law, whereby the U.S. system depends on case law. Code law systems are particularly dependent on variety-oriented clients and rely not only on shareholder interests, but also on rendering environmental management an important method to minimize conflicts of interest.

Previous studies documented the effect of code and case law legal frameworks on sustainability management behavior. Study is divided into French (e.g., France, Portugal, Spain) and German (e.g., Austria, Germany and Switzerland) Code Rules. Singh et al (2019) explained that annual surveys of agricultural cooperatives are conducted by the USDA each year. The survey reports showed the number of agricultural cooperatives present in United States of America, although, on the other side, gross amount continues to decline without interruption. During 2000-2016, the number of agricultural cooperatives dropped from 3338 to a little 1953. The gross volume shot up from $\$ 118.9$ billion to $\$ 191.1$ billion over the same period. Trends have been credited towards smaller and larger agro-cooperatives and have awareness of the causes of such transition. The degree of achievement of the U.S. cooperatives is often expressed in their financial output, calculated conventionally by the use of accounting ratios.

As per previous studies, for such transition, the role of technology has been well known. Other variables have also contributed, such as financial determinants, instability, institutional inventions, and the efficiency of human resources. From Prombutr and Phengpis (2019), creating characteristic-balanced (CB) collections, resolved the correlation problem. The $\mathrm{CB}$ collections were zero-cost collections with a long position in high factor loading collections and a short position after monitoring for company features such as market size and ratio of book to market in low factor loading collections. On the other hand, the $\mathrm{CB}$ collections have a substantial positive average return if the company-feature statement is correct, since the firm features are the real driver which are now in check. Sadaf (2019) stated that the investment of companies also has an effect on their dividend policy choices. In the theoretical sense of Miller and Modigliani (1961), relationships between dividend and investment decision policies are clear.

This theory argued that a flawless capital market is sovereign by the process of funding those choices, optimal investment choices by businesses. As investment choices were not judged by dividends, the core principle had a significant outcome, and dividend decisions had no impact on investment choices. Empirical proof of violence to the theorem was proven in this view. Subsequently, there was no indication of an established relationship between dividends and investment choices that needed simultaneous equation models (SEM) to provide them. Alqattan and Alhayky in (2016) analyzed relation that exist the prices of oil as well as the price on the stock market in GCC between 2006-2015. The study found that fluctuations in oil prices played an important role in defining the short-term fluctuations in stock market prices in GCC countries. This research also found that in GCC countries but in Oman, the long-run market stock price is insensitive to prices of oil variations.

\section{CONCLUSION}

Capital structure philosophers such as pecking order theory, market signal theory, and agency theory have checked the out-of-date trade-off theory because debt capital is presented as behavioral characteristics in the capital structure because of less power and knowledge needed for the function of the pecking order, a way to improve directors' professional ambition. Theorists have argued that capital structure adversely affects the efficiency of an organization and therefore; managers cautiously use debt capital to foot cost activity. The findings suggested that, instead of rising the percentage of equity capital in their capital structure mix, companies should reduce the use of debt capital. Furthermore, the analysis finalizes clear findings with the theory of 
agencies, pecking order theory, and the theory of market signals. The findings support the various stakeholders as well as the owners of the corporations, the government, the stockholders, the finance practitioners, and the academic society. The results provide support for owners, especially stakeholders with managerial influence in the business. It is also important to understand how to cut down managers' excesses because they engage in business resources to improve the value of the company rather than the benefits that are contrary to the wealth of smaller owners.

\section{REFERENCES}

Al Salamat, W. A., \&t Mustafa, H. H. (2016). The impact of capital structure on stock return: Empirical evidence from Amman stock exchange. International Journal of Business and Social ScienceVol, 7.

Andersson, M. (2016). The effects of leverage on stock returns.

Ariyani, H. F., Pangestuti, I. R. D., \&t Raharjo, S. T. (2019). The Effect Of Asset Structure, Profitability, Company Size, And Company Growth On Capital Structure (The Study Of Manufacturing Companies Listed On The Idx For The Period 2013-2017). Jurnal Bisnis Strategi, 27(2), 123-136

Avc1, E. (2016). Capital structure and firm performance: An application on manufacturing industry.

Balouei, E., Anvary Rostamy, A. A., Sadeghi Sharif, S. J., Et Saeedi, A. (2018). The impacts of financial structure on financial performance of banks listed in Tehran Stock Exchange: An empirical application. Advances in Mathematical Finance and Applications, 3(3), 11-26.

Bambang, B. S., \&t Mukhtaruddin, M. (2015). Intellectual capital, firm value and ownership structure as moderating variable: Empirical study on banking listed in Indonesia Stock exchange period 2009-2012. Asian Social Science, 11(16), 1-12.

Boller, L., \& Morton, F. S. (2020). Testing the theory of common stock ownership (No. w27515). National Bureau of Economic Research.

Cho, S. J., Chung, C. Y., \& Young, J. (2019). Study on the Relationship between CSR and Financial Performance. Sustainability, 11(2), 343.

Dou, W., Ji, Y., Reibstein, D., \& Wu, W. (2019). Customer capital, financial constraints, and stock returns. Financial Constraints, and Stock Returns (February 7, 2019).

Ghosh, T. P. Economic Diversification and the State of Oil Dependency of UAE Stock Returns-An Analysis of ADX Indices 2014-2019.

Hossain, A. T., \&t Nguyen, D. X. (2016). Capital structure, firm performance and the recent financial crisis. Journal of Accounting and Finance, 16(1).

Ligocká, M., \&t Stavárek, D. (2019). The relationship between financial ratios and the stock prices of selected
European food companies listed on Stock Exchanges. Acta Universitatis Agriculturae et Silviculturae Mendelianae Brunensis, 67(1), 299-307.

Liu, Z. (2020). Unraveling the complex relationship between environmental and financial performance A multilevel longitudinal analysis. International Journal of Production Economics, 219, 328-340.

Murtaza, S., \&t Azam, I. (2019). The Relationship between Ownership Structure and Capital Structure: Evidence from Chemical Sector of Pakistan. SEISENSE Journal of Management, 2(4), 51-64.

Murtaza, S., \& Isra, A. (2019, June). The_Relationship_ between_Ownership_Structure_and_Capital_Structure. Retrieved from https://www.researchgate.net/ publication/333548951_: https://www.researchgate.net/ publication/333548951_The_Relationship_between_ Ownership_Structure_and_Capital_Structure

Ngome, A. L. (2016). The effect of capital structure on stock returns for firms listed on the Nairobi securities exchange (Doctoral dissertation, University of Nairobi).

Nuber, C., Velte, P., \&t Hörisch, J. (2020). The curvilinear and time-lagging impact of sustainability performance on financial performance: Evidence from Germany. Corporate Social Responsibility and Environmental Management, 27(1), 232-243.

Prombutr, W., \&t Phengpis, C. (2019). Behavioral-related firm characteristics, risks and determinants of stock returns. Review of Accounting and Finance.

Rajhans, R. K. (2013). Financial determinants of firm's value: evidence from Indian firms. ZENITH International Journal of Business Economics \&t Management Research, ISSN, 2249-8826.

Sadaf, R., Oláh, J., Popp, J., \&t Máté, D. (2019). Institutional ownership and simultaneity of strategic financial decisions: An empirical analysis in the case of Pakistan Stock Exchange.

Singh, A. K., \&t Bansal, P. (2016). Impact of Financial Leverage on Firm's Performance and Valuation: A Panel Data Analysis. Indian Journal of Accounting, 2, 73-80.

Singh, K., Misra, M., Kumar, M., \&t Tiwari, V. (2019). A study on the determinants of financial performance of US agricultural cooperatives. Journal of Business Economics and Management, 20(4), 633-647.

Talwar, S. (2020). Dynamics of Firm Value, Financial Performance, Leverage, and Governance: A Panel Data Analysis of Listed Indian Firms. International Journal of Business, 19(2), 131-149.

Yudha, K., Sri, H., \&t Ahmad, M. T. N. (2019). the Impact of Financial Performance and Macroeconomics on the Stock Returns of the Company in Construction and Building Subsectors. Russian Journal of Agricultural and Socio-Economic Sciences, 86(2). 